MELNYK Myroslav Tarasovych

$\mathrm{PhD}$ in Art Theory and History, docent, professor of Art Textile and Costume Design department, Kyiv State Academy of Decorative and Applied Art and Design named after Mykhailo Boychuk, Orcid ID: 0000-0002-0494-9403 e-mail: 5445941@ukr.net

\title{
TRADITIONAL UKRAINIAN COSTUME IN THE CONTEXT OF NATIONAL LIBERATION AND SOVIET OCCUPATION IN 1920s
}

\begin{abstract}
Визначаються основні елементи традииійного украӥнського костюма, які слугували для самоідентифікації та демонстрачії патріотичних переконань українців на початку XX cm. Аналізуеться місие традиційного українського костюма та його впізнаваних елементів у контексті національно-визвольних рухів в Україні та визначається їх роль у ствердженні національної ідентичності перед більшовицькою окупацією і протягом раннього радянського періоду в Східній Україні. Визначаються традиційні елементи, які стали базовими в дизайні вітчизняного модного костюма в 1920-х, аналізуються причини перетворення етнодизайну на кітч в період сталінізму.
\end{abstract}

Ключові слова: традииійний костюм, украйнська вишивка, вишиванка, радянська мода, мода 1920-х, етнодизайн, кітч.

Introduction. Like many other nations, Ukrainians have a necessity of self-determination and its visual presentation. During the years when Ukraine was under the rule of empires, to wear traditional costume, as well as to use the Ukrainian language, has been a symbolic ostensible patriotism. In the first decades of the twentieth century the foundations of domestic fashion design was settled and Ukrainian traditional costume has become an important source of creators' inspiration. Today it is relevant and important to track how the tradition was adapted to the fashion trends and to the ideological attitudes of the Soviet regime and why traditional elements became kitsch later.

Recent researches and publications. Different aspects of folk costumes (and widely - the national style in clothing) was studied by many leading anthropologists, culturologists and art critics. Among them, in particular, are modern Ukrainian scientists Tamara Nikolaeva [1], Zinaida Vasina [2], Tetiana Kara-Vasylieva [3], Zenovia Tkanko [4], Maryna Olijnyk [5]. Djurdjia Bartlett [6], Andrey Boborykin and Sophia Egorova [7] devoted their works to the analysis of fashion in the Soviet Union.

The purpose of the article is to determine the main elements of traditional Ukrainian costume, which served to underscore the Patriotic beliefs of Ukrainians in the early twentieth century and to analyze these recognizable elements in the context of fashion design.

Results. At the end of nineteenth - beginning of the twentieth centuries Ukraine was under the repression of the Russian and Austro-Hungarian empires. Ukraine was not political, but rather cultural community - the nation, connected with relationships that rooted deeply in a cultural heritage. Ukrainians wanted their states independence; their aims were to cherish their ethnical traditions and to develop their unique nation. These processes clearly reflected in works of literature, fine and applied arts. Also that national aspiration found its specific manifestation in the field of costume. 
For the majority of the Ukrainian population, the problem of identity choice was the rejection of the social (Cossacks, serfs, farmers), religious (Orthodox, Greco-Catholics, Jewish), regional (Ruthenians, Boyky, Lemky, Hutsuls) and other identities and providing benefits to the national concept of «Ukrainian». In Ukraine traditional national costume was a costume of peasants, which belonged to the lower, the most disenfranchised class. Ukrainian costume has certain distinctive features in different regions. For example, in the book "Ukrainian folk costume" authors presented seventeen variations of the Ukrainian folk costume [8]. Summarizing and discarding the distinctive elements, we can select the most common: vyshyvanka (white embroidered shirt), kraika (sash), svyta (outerwear), kersetka (woman's vest), plakhta (festive panel skirt), zapaska (apron), korali (bead necklace). These elements provide Ukrainian style to the costume.

At the beginning of the twentieth century Ukrainian folk costume was not only a sign of patriotic, but also of democratic feelings. The introduction of traditional peasant elements into costumes of "upper classes" and urban clothing expressed the identification with the interests of common people, the recognizing of social equality, the willingness to fight against any oppression, for freedom of the nation as a whole. It raised the traditional peasant costume to the level of the national symbol and revealing tensions between narratives of nationhood and various interpretations of what "proper" patriot should be.

The deployment of creative intellectuals for the revival and updating of the national costume was observed in the second half of the nineteenth century. The most important element in both genders costumes was white embroidered shirt - vyshyvanka. Men wear the vyshyvankas, combining them with classic costumes of the English type. In women costumes vyshyvankas was supplemented by fashionable skirts. Fashionable women also decorated art nouveau dresses with Ukrainian embroidery, wearing korali. Also it was fashionable for a man to have long thick moustache (Cossack mustache), women made braids which were wound around the head. Suffice it to recall the famous photos of Olena Pchilka, Lesia Ukrainka, Dmytro Antonovich, Ivan Franko and many others dressed in costumes with Ukrainian traditional elements and emphasizing their national beliefs this way.

The appreciation of folk costume was strongly reflected in many works of art. For example, in the plays of Mykhailo Starytsky "Ne sudylos» (It Was Not Destined, 1881), «Za dvoma zaitsiamy» (After Two Hares, 1883) and «Po-modnomu» (Fashion-like, 1887) the author depicts caricature heroes caring too much about «modern shaped fashion» clothes, made from precious foreign materials. Contrary, all positive characters of Starytsky's plays wear elements of the Ukrainian traditional costumes [9].

We must note that at the beginning of the twentieth century one of the important reasons for traditional costume popularization was a fast development of capitalism accompanied by urbanization. People wore folk costumes, trying to struggle against the unification and (or) to keep some symbolic connection with abandoned relatives and native villages. Very soon industrial production pushes away the self-made materials, hand-sewing and embroidery. Instead, inexpensive factory-made yarn and fabrics appeared. They had new plastic qualities and were painted in bright colors of aniline dyes. Fabric materials demanded the new technologies for production, new fashion styles and new routines of consumption. The problem of transforming centuries-old handicraft traditions into the design and industrial mass production of modern costumes was very important at that time.

During the 1910 - 1920s in Ukraine a number of ateliers and cooperatives established; they actively restored the tradition of folk clothing. Ukrainian woman periodicals supported the national style in fashion, promoting folk traditions of sewing and embroidery, providing the samples and tips for homemade crafts. 
Alexandra Ekster, Yevgenia Pribylska, Hanna Sobachko-Shostak and many other artists of decorative and applied art developed the Ukrainian version of most fashionable Art Deco style. Their creations based on Ukrainian traditions and at the same time modern ideas, new experiences and techniques.

Alexandra Ekster was a painter and a designer of international stature who divided her life between Kiev, Moscow and Paris. Ekster developed her own original style, absorbed from many sources and cultures. In 1915-1916 she worked in the peasant craft cooperatives along with Kazimir Malevich, Yevgenia Pribylska, Natalia Davidova and others. She founded a teaching and production workshop in Kiev in 1918 [10]. But the political situation in Ukraine was further complicated at that time. The Bolsheviks declared the Central Rada counter-revolutionary and started a war against Ukrainian government. Immediately after the beginning of Soviet occupation Ukrainian national motifs were approved by the official ideology.

The official perception of Ukrainian traditional culture in the Soviet Union was complex and controversial. Soon after the proclamation of the New Economical Politic (1921), the government embarked on a policy of mass Ukrainization (1923). Embroidered shirts and other elements of Ukrainian traditional costume became the ceremonial clothing of the representatives of the new Soviet authorities. However, the new government condemned artistic interpretations of national culture as the «nationalism» very quickly.

Alongside with the return of folk traditions, Ukrainian artists and designers wanted to make clothing correspond to modern way of life and its demands. They believed that the efficient Soviet clothing had to be distinctly new to replace pre-revolutionary traditional dress. Alexandra Ekster wrote in 1921: «The pace of contemporary life demands the least expenditure of time and energy on production. To contemporary fashion changing according to the whims of businessmen, we must oppose clothes which are both practical and beautiful in their simplicity. The dress for general consumption must be made from the simplest geometrical forms, such as the rectangle, the square, the triangle; the rhythm of colors varies the impact of the form. They are quite utilitarian since they are constructed from a combination of parts and, in putting them on or taking them off, the wearer dramatically modifies both the form and its purpose» [11].

Besides her eclectic avant-guard-like style, Ekster's essential futurist and cubist costumes were always in tandem with her attention to the color and rhythm, which based on the Ukrainian traditions.

Yevgenia Pribylska studied and restored Ukrainian traditional ornaments, using them to develop original stylized compositions, in which she combined folk motifs with the latest discoveries of avant-garde art. Pribylska also adapted East Galician embroidery for the industrial manufacture of clothing. She theoretically substantiates the feasibility of decorating fashion suit with embroidery and insisted that an embroidery cannot be a self-sufficient element and, like in the Ukrainian traditional costume, embroidery should build things together with the fabric. In her opinion, the precise texture and color rhythms of embroidery can organically link the elements of clothes into a single unit, to smooth the impression of poor color or material [11]. These ideas were particularly relevant in the context of the Soviet deficit. But at the same time Pribylska recognized that the embroidery is a luxury, which has a very limited scope. She wrote, that handmade embroidery could not improve the quality of mass production and traditional motifs need to be modernized so that they seamlessly blended into the aesthetics of European clothing of the mid-1920s [12].

Hanna Sobachko-Shostak worked with Yevgenia Pribylska in the peasant craft cooperatives before the Soviet came to Ukraine. Her drawings were made of panels and embroidery, which were successfully exhibited in Kiev, Paris, New York, Saint Pietersburg and Moscow. The compositions of Hanna Sobachko-Shostak were lyrical and yet epic. She had used the principles of folk painting with intense colors and clear patterns. 
Shortly after the Soviet occupation further development of Ukrainian fashion came under the influence and direct instructions from Moscow. Theoretical and ideological center of the Soviet fashion become the "Moscow sewing house", founded in 1923. To work there, Alexandra Ekster and Evhenia Prybylska had to move to Moscow. Working there under the leadership of Russian Couturier Nadezhda Lamanova, Ukrainian designers continued to revive and popularize the Ukrainian folk costume elements, using the traditions of cutting and embroidery.

Basing modern costumes on embroidered decoration, designers used the constructions of rectangular shape, lending it to simple cuts. They used inexpensive material onto which the embroidered works were sewn, creating a silhouette and elongated proportions popular in European fashion.

In 1925 at the Parisian «Exposition Internationale des Art Decoratifs et Industriels Modernes» (International exhibition of modern decorative arts and crafts), the collaboration of Nadezhda Lamanova, Alexandra Ekster and Evhenia Prybylska got a Grand prix [13, 211].

Despite the aesthetic perfection and the compliance with the 1920-s fashion, it was unaffordable luxury for the majority of Soviet women. In those days Soviet industry was still coping with the deficiencies and shortages of the civil war. The only available textiles were unprinted fabrics; linen canvas, tarpaulin, soldier's cloth, lowgrade woolens, thick flannelette, coarse calico and cotton $[6,61]$.

It is significant that next to the Grand prix, the Golden medal at this Paris International exhibition won the clothes, made on the drawings by Vera Bolsunova, who was a connoisseur of Ukrainian folk art. Bolsunova organized the enterprise of art products in Poltava in 1917 and later she worked in industrial societies [10,47].

This great success achieved by small resources was a testament to the fact that the leading Ukrainian masters of embroidery and costumes design achieved the highest level of couture. They found the principles of combining European fashion with national features, which can be used in today's fashion design. They widely used the experience of various artistic movements and trends, boldly experimented with colours, textures, volumes, flexibility. The designers have adapted and simplified ethnic ornaments to combine them with fashionable shapes and silhouettes. Their highly artistic, aesthetically expressive work promoted the ethnic fashion trends of not only in Ukraine, but also in 1920s Europe. For example, ethnic motifs were noticeable in the Haute Couture collections of such leading French designers as Gabrielle Chanel, Jeanne Lanvin and Paul Poiret $[13,211]$. But for European designers ethnic embroidery was just an exotic element, which became unfashionable very soon.

Following the recognition at the Exposition Internationale, soviet designer's creations supposed to be a representative schema of the Soviet democratization and modernization of life. They showed that the preference of Soviet shopgirls was not for shoddy silks but for elevated peasantry. This celebration of a rural tradition, embroidery, was a fortuitous circumstance for the regime, it created a sense of national continuity and assisted in distracting attention from the effects of the Stalin's policy of enforced collectivization.

Dr. Jon Cockburn noted: «The younger woman's dress carries the new design in its simplicity of cut and, importantly, in the incorporation of peasant embroidery, although more generous with material than the original template. The older woman represents several readings. The first is conventional: a return to the stable and traditional moral values some felt had been threatened during the early years dominated by left communism. The second is that she acts as both a contrast and a link between the «was then, is now» of the Russian past and the Soviet present. The younger woman represents what was not available to the older woman in her youth, but is now, thanks to Communism. Thirdly and somewhat paradoxically, the older peasant woman is the source, if not keeper, of the technique of embroidery» [14, 16-17]. 
After the abandonment of the New Economical Politic, government formed the new ideology of consumption, the cornerstone of which was a household asceticism: the desire to save the Soviet people from the bourgeois cult of things. In the new reality of things the Soviet people had to be content with needs, not «perverted» desires. The competition for furs, jewelry and even high-quality fashionable clothes condemned as a waste. The display of wealth was immoral. Clothing had to be warm, protect from cold, and not to display prosperity in a country where all are equal.

But it was contrary to the traditional values of the Ukrainian people. The traditional Ukrainian costume served to demonstrate the mastery of women and the viability of her family: a thin white cloth and rich embroidery, beads, sloe woolen shawls, silk ribbon and other luxury elements - all this was a source of pride and praise, the subject of conspicuous consumption. It motivated people to work and to be proud of their gains.

After Joseph Stalin put his First Five Year Plan into motion in 1928, the Soviet government began to criticize and censor folklore. The Soviet regime have believed that national traditions supported the old tsarist system and the capitalist economy. They saw it as a reminder of the past. The well-dressed people suffered of harassment and "punching" for "bourgeoisie" clothes. Public opinion on this issue was unchanged: if you have enough money and time to look good, then you don't work hard enough to build the Communist society. And it spread not only the perception of clothing but also on the appearance: the femininity was considered as an attribute of the class enemy, as a sign of eroticism and decadence $[6,50]$.

Soviet ideology argued the use of folklore because it was the tradition of the working people and consequently could be used to motivate and inspire collective projects amongst the presentday proletariat. In Communists' eyes, traditions sufficiently promoted the collectivist spirit and showed the Soviet regime's benefits and progress. Further development of crafts in this direction gave rise of kitsch, when traditional Ukrainian culture developed and perceived in the world as a part of «Big Russia», and works of decorative and applied art were ornamented with patterns of «sickles and hammers», Communist slogans or portraits of Lenin, Stalin and other Soviet leaders.

Later, Soviet artists created individual works, which did not come from the traditions of the working class and consequently today it is perceived as a pseudo-folklore, rather than genuine Soviet folklore. The fashion design was developed in the context of the country's isolation from contemporary art processes. It was almost required to design the clothes with folk elements. Without any true connection to the national traditions and without compliance with the contemporary trends, Soviet fashion design with ethnic elements was just a falsehood.

Conclusions. Analyzing the traditional Ukrainian costume and its' elements in the context of 1920s shows that it was important way of expressing the national identity. There were two directions to use traditional elements to create a modern costume: in tune with fashion updating the traditions becomes harmonious and the conservative or idialogized use of traditions turns it into kitsch.

\section{Список використаної літератури}

1. Ніколаєва Т. О. Український костюм. Надія на ренесанс / Тамара Ніколаєва. - К.: Дніпро, 2005. $-320 \mathrm{c}$.

2. Васіна 3. О. Український літопис вбрання: [Книга-альбом]. Т. 2. XIII - початок XX ст.: Наук.худож. реконструкції. Текстівки, рез. англ., рос. / 3.О. Васіна. - К. : Мистецтво, 2006. - 448 с.

3. Кара-Васильєва Т., Чегусова 3. Декоративне мистецтво України ХХ століття. У пошуках «великого стилю»/ Тетяна Кара-Васильєва, Зоя Чегусова. - К.: Либідь, 2005. - 280 с.

4. Тканко 3. Мода в Україні XX століття / Зеновія Тканко. - Львів: Артос, 2015. - 236 с.

5. Олійник М. Український одяг у системі міської культури Києва (друга половина XIX - початок XXI століття): монографія / Марина Олійник. - К., 2017. -312 с. 
6. Бартлетт Дж. Fashion East. Призрак, бродивший по Восточной Европе / Дж. Бартлетт. - Москва : Новое литературное обозрение, 2011. - 360 с.

7. Бобрихин А. А., Егорова С. И. Одежда и мода как средство формирования советской идентичности // Концепт. - 2015. - Спецвыпуск № $18-6$ с.

8. Український народний одяг = Ukrainian Folk Costume / [ред.: П. Одарченко, Г. Царинник ; пер. англ. О. Пащак-Трач ; іл.: Г. Титла та ін.]. - Toronto; Philadelphia: Світ. Федерація Укр. Жіночих орг., Коміс. нар. мистецтва, 1992. - 311 с.

9. Старицький М. П. Поетичні твори. Драматичні твори / М. П. Старицький. - К.: Наукова думка, 1987. $-576 \mathrm{c}$.

10. Кара-Васильєва Т., Чегусова 3. Декоративне мистецтво України XX століття. У пошуках «великого стилю» / Тетяна Кара-Васильєва, Зоя Чегусова. - К.: Либідь, 2005. - 280 с.

11. Экстер О. О конструктивной одежде // Ателье, 1923, № 1, С. 4-5.

12. Прибыльская Е. Вышивка в настоящем производстве // Ателье. - 1923. - № 1. - С. 7-8.

13. Васильев А. А. Русская мода. 150 лет в фотографиях / Александр Васильев. - Москва : Слово/ Slovo, 2004. $-447 \mathrm{c}$.

14. Cockburn, Jon. Clothing the Soviet Mechanical-Flвneuse. The Space Between. Australia: University of Wollongong, 2005.

\section{References}

1. Nikolayeva, T. O. (2005). Ukrainian costume. Hope for Renaissance. Kyiv: Dnipro (in Ukr.).

2. Vasina, Z. O. (2006). Ukrainian chronicle of the dress. Kyiv: My'stecztvo (in Ukr.).

3. Kara-Vasyl'yeva, T., Chegusova, Z. (2005). Decorative art of Ukraine of XX century. In search of the "Grand style". Kyiv: Lybid" (in Ukr.).

4. Tkanko, Z. (2015). Fashion in Ukraine of the XXth century. L'viv: Artos (in Ukr.).

5. Olijny'k, M. (2017). Ukrainian clothes in the system of urban culture of Kyiv (the second half of the XIX - early XXI century): monograph. Kyiv (in Ukr.).

6. Bartlett, Dzh. (2011). FashionEast. The Ghost that roamed Eastern Europe. Moscow: Novoe lyteraturnoe obozrenye (in Russ.).

7. Bobry'xy'n A. A., Egorova S. Y. (2015). Clothes and fashion as a means for forming of the Soviev identity. Koncept. Special issue \#18 (in Russ.).

8. Ukrainian Folk Costume (1992). In Odarchenko P., Tsarynnyk H. ed. Toronto; Philadelphia: Svit (in Ukr.).

9. Starycz'kyj, M. P. (1987) Poetic works. Dramatic works. Kyiv: Naukova dumka (in Ukr.).

10. Kara-Vasyl'yeva, T., Chegusova, Z. (2005). Decorative art of Ukraine of XX century. In search of the "Grand style". Kyiv: Lybid" (in Ukr.).

11. Ekster O. (1923). About constructive clothing. Atel'e, 1923, \# 1(in Russ.).

12. Prybyl'skaya E. (1923). Embroidery in this production. Atel'e, 1923, \# 1, (in Russ.).

13. Vasyl'ev A. A. (2004). Russian fashion. 150 years in photography. Moskow: Slovo (in Russ.).

14. Cockburn, J. (2005). Clothing the Soviet Mechanical-Flsneuse. The Space Between. Australia: University of Wollongong.

МЕЛЬНИК Мирослав Тарасович, кандидат мистецтвознавства, доцент, професор кафедри художнього текстилю та моделювання костюма, Київська державна академія декоративноужиткового мистецтва та дизайну імені Михайла Бойчука,

\section{ТРАДИЦЙНИЙ УКРАЇНСЬКИЙ КОСТЮМ ДОБИ ВИЗВОЛЬНИХ ЗМАГАНЬ І РАДЯНСЬКОЇ ОКУПАЦІї 1920-х рp.}

\footnotetext{
Abstract. Introduction. During the years when Ukraine was under the rule of empires, Ukrainians have a necessity of self-determination and its visual presentation. To wear traditional costume has been a symbolic ostensible patriotism. When the domestic fashion design was settled, the Ukrainian traditional costume has become an important source of inspiration.
} 
The purpose of the article is to determine the main elements of traditional Ukrainian costume, which served to underscore the patriotic beliefs of Ukrainians in the early twentieth century and to analyze these recognizable elements in the context of fashion design.

Results. At the end of nineteenth - beginning of the twentieth centuries Ukraine was not political, but rather cultural community. Ukrainians wanted to develop their unique nation. This national aspiration found its specific manifestation in the field of costume: vyshyvanka (white embroidered shirt), kraika (sash), svyta (outerwear), kersetka (woman's vest), plakhta (festive panel skirt), zapaska (apron), korali (bead necklace) provide Ukrainian style to the costume as the sign of patriotic feelings. The problem of transforming centuries-old handicraft traditions into the design and industrial mass production of modern costumes during the 1910 - 1920s has been solved by Alexandra Ekster, Yevgenia Pribylska, Hanna Sobachko-Shostak and other designers and artists of applied arts. Their creations based on Ukrainian traditions and at the same time modern ideas and techniques. The official perception of Ukrainian traditional culture in the early ears of Soviet Union was complex and controversial, but design findings of Ukrainian creators were in demand both in Moscow and abroad. They found the principles of a harmonious combination of European fashion with national features, which can be used in today's fashion design.

After Joseph Stalin put his First Five Year Plan in 1928, the Soviet government began to criticize and censor folklore and its further development gave rise of kitsch, when traditional Ukrainian culture developed in the context of the country's isolation from contemporary art processes, as a part of "Big Russia". The works of decorative and applied art were ornamented with patterns of "sickles and hammers", Communist slogans or portraits of Soviet leaders.

Originality of the research is that the Ukrainian costume and its iconic elements are considered in the context of national self-determination and modernization of life.

Conclusion. Analyzing the traditional Ukrainian costume and its' elements in the context of $1920 \mathrm{~s}$ shows that it was important way of expressing the national identity. The creation of a modern costume based on traditional elements was harmonious and successful when fashion trends were taken into account. Political ideologization of traditions turns them into kitsch.

Keywords: traditional costume, Ukrainian embroidery, embroidery, Soviet fashion, 1920s fashion, ethnic design, kitsch.

Одержано редакцією 16.05.2019

Прийнято до публікації 2.09.2019

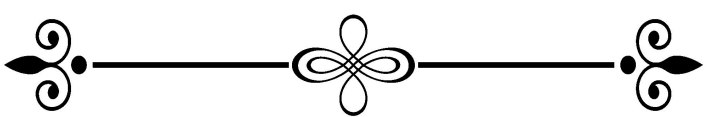

